\author{
(online) $=$ ISSN $2285-3642$ \\ ISSN-L = $2285-3642$ \\ Journal of Economic Development, Environment and People \\ Volume 9, Issue 2, 2020 \\ URL: http://jedep.spiruharet.ro \\ e-mail: office jedep@spiruharet.ro
}

\title{
An Overview on Romanian Strategies regarding Roma Minority Concerning Education and Employment
}

\author{
Laura Patache ${ }^{1 ⿴ 囗 十) ~ a n d ~ O c t a v ~ N e g u r i t ̦ a ̆ ~}{ }^{2}$ \\ ${ }^{1}$ Spiru Haret University, Romania \\ ${ }^{2}$ Spiru Haret University, Romania
}

\begin{abstract}
According to the Council of Europe, Roma population in Romania is about $8.6 \%$ representing the largest minority group, exceeding the Hungarian ones. Demographic trends make the problem of the Roma minority even more stringent, through the fact that the population is aging despite Roma's positive natural increase. Romanian Government elaborated a Strategy to improve conditions for the Roma, which is permanently updated according to political commitment at the international level, based on the following guiding principles: consensuality, social utility, sectorial division, decentralization in execution, legislative compatibility, identity differentiation, and equality. Education is the key to better access to the labor market and in the last two decades authorities have taken several actions concerning Roma social inclusion, but the results are not the ones expected. It is a fact that, especially in the case of children, low life's level, marginalized communities, rural areas, culture, and traditions may generate social exclusion and inequality. The study aims to make an overview of the Romanian governmental policies regarding the improvement of the situation of the Roma minority, especially regarding education and employment. The results of the study could be useful for a better correlation of social policies with an impact on the living of Roma.
\end{abstract}

Keywords: Roma minority, education, socially assisted, traditions, employment policies, scattered minorities

JEL Codes: 124, J21, J28, J48, J78

How to cite: Patache, L., Neguriță, O. (2020). AN OVERVIEW ON ROMANIAN STRATEGIES REGARDING ROMA MINORITY CONCERNING EDUCATION AND EMPLOYMENT. Journal of Economic Development, Environment and People, 9(2) DOI: https://doi.org/10.26458/iedep.v9i2.666

\section{Introduction}

This article refers to Roma as a wide diversity of groups: sedentary (caldărari, costorari, gabori, lingurari, etc.) and nomads/travelers (gypsies), too.

The Romanian Census of Population from 2011 reveals that the Roma population was 621,573 people (3.1\% of the total population) of which $50.8 \%$ were male and about $52 \%$ were children and youth. The Roma population increased with $15.6 \%$ in less than 10 years (since 2002 Census of Population) and is

${ }^{+}$Corresponding author. Tel.: +04241545015, E-mail address: laura.patache@spiruharet.ro. 


\author{
(online) = ISSN $2285-3642$ \\ ISSN-L = $2285-3642$ \\ Journal of Economic Development, Environment and People \\ Volume 9, Issue 2, 2020 \\ URL: http://jedep.spiruharet.ro \\ e-mail: office jedep@spiruharet.ro
}

relatively uniformly distributed throughout the country (less than $10 \%$ of total but more than 40,000 persons only in counties such as Mures and Dolj).

Other sources consider the number of Roma in Romania is higher, such as the Council of Europe estimates Roma population between 1.2 and 2.5 million, an average of 1,850,000 (8.63\%) in 2011; between 730 and about 968 thousand persons in 2002 [33], 1.4 and 2.8 million people [34] and so on.

The discrepancy is often explained by the reluctance among Roma to self-identify for fear of stigmatization and discrimination or as a consequence of the process of assimilations in the communist period. [18] Also, 'Roma identity is not readily claimed, especially among the more educated'. [35, p.15]

Poverty and social exclusion, low level of education, and important flows of migration are the major problems for the Roma communities, even that they are recognized as a minority in our country.

The poverty of Roma, especially in the case of children, is a concern of politics, NGOs, and scholars, too. The Roma population is three times poorer than the all Romanian population, as a consequence of low levels of health and education, limited opportunities on the labor market, and discrimination. [30, p.7]

After the Romanian accedes to the EU, the Roma population 'turn to migration for survival' many of them entering to the informal labor market for an income or begging for money [13, p.2] In an article which reveals the impressions of the Roma life through the eyes of Gipsy community located in Craiova, Dolj county, the Roma rely on some ridiculous social aid ('one hundred RON and something' - about 20 Euro n.m.), from the allowances of children who grow up in the shadow of one hope: that one day they will go "abroad", begging. [3]

The fact that the Roma are a scattered minority involves only a non-territorial autonomy (NTA) based on the lack of inclusiveness, homogeneity, and compactness [4, p.7].

The national fundamental law provides that the state recognizes and guarantees to the persons belonging to national minorities the right to preserve, develop and express their ethnic, cultural, linguistic and religious identity' (article 6 paragraph 1)) and 'they have the right to speak in the native language before the courts' (article 128). [29]

In Romania the Roma minority has a form of NTA from cultural and linguistic perspectives and also, we can talk about positive discrimination according to the rules of socio-economic programmes implemented at the national and regional levels.

Some scholars even recognize the role of positive discrimination (e.g. positive discrimination that takes as a reference point the past, state that nowadays society is in debt to the victims of the past discriminations because, even if the phenomenon of discrimination of some social groups ceased, the descendants of the direct discrimination victims continue to be indirect victims, because placed in the competition with the other members of the society they started from a disadvantaged position); they draw attention to the negative effects that these measures can generate on the targeted community or group. In some cases, 'positive discrimination produces tensions, animosity, conflicts, and discourages cooperation through competition among individuals' and not favors integration. [14]

In 2004, based on the Governmental Ordinance no.78/2004, approved by Law no. 7/ 2005, it was set up the National Agency for Roma (NAR), a specialized body of central public administration, with legal personality, subordinated to the Government and coordinated by the General Secretariat of the 


\author{
(online) $=$ ISSN $2285-3642$ \\ ISSN-L = $2285-3642$ \\ Journal of Economic Development, Environment and People \\ Volume 9, Issue 2, 2020 \\ URL: http://jedep.spiruharet.ro \\ e-mail: office jedep@spiruharet.ro
}

Government. NAR is organized and operates according to Governmental Decision no. 1703/2004, amended and supplemented. In cooperation with institutions and non-governmental organizations, NAR initiate, participate and promote activities, projects and sectoral programs to improve the situation of Roma people. Its main object of activity is to ensure the complementarities of various public policies for Roma people, initiated at the national and international level, to coordinate and monitor their implementation.

\title{
2. Strategies regarding Roma minority
}

Starting by 2001, Romanian Government elaborated a Strategy to improve conditions for the Roma, National Roma Integration Strategies (NRIS), which is permanently updated according to political commitment at the international level, based on the following guiding principles: consensuality, social utility, sectorial division, decentralization in execution, legislative compatibility, identity differentiation, and equality.

First NRIS was implemented during 2001- 2010 with the most successful outcomes trough the Roma Health Mediator programme, which improves Roma access to healthcare services and decreased disparities between Roma and non-Roma in Romania [26, p.6].

The NRIS for 2015-2020 was revised in the light of Europa 2020 - EU strategy and aims to be: better (especially, to improve the situation of the human resource provided by the Roma population, one of the youngest in Romania), integrated (by the education point of view measures), consensual (permanent partnership with civil society in all stages of local and central public' intervention) and customized (adapted to the social particularities that characterize some subgroups of the Roma minority). [31]

The main directions of action for NRIS are education, employment, health, housing, culture, and social infrastructure.

\section{Roma education}

Despite the national and international programmes that aimed to the inclusion of Roma children within the mainstream education system on an equal basis with all other children, the Romanian educational system is characterized by a low level of enrolment in kindergarten and barriers in enrolment in primary education for Roma children; lack of adequate desegregation policies and enforcement measures; a system of financing and administering education that does not support children, discriminating against them those in poor families; major differences in the quality of education caused by the standards resulting from different curricula. Also, Roma culture is not recognized in school and school curricula and forms of multicultural education are rarely part of the process of teacher education or training. [30, p.8] To sustain the inclusion of Roma people in Romania, during the period 1999-2010 have been allocated 157.3 million Euros through European funds (75.1\%), state budget funds (10.4\%) and BIRD reimbursable funds (14,5\%). $[21$, p.3]

According to the official data (NIS, 2002, and 2011), the illiterate population of 10 years and over of Roma ethnicity decreased from 104,737 persons in 2002 (25.6\% from total) to 67,480 (14.1\%) in 2011. The share of the illiterate population remained more than 10 times higher that of all Romanian citizens and even more serious in the case of the female population or coming from the rural area. The Roma 


\author{
(online) = ISSN $2285-3642$ \\ ISSN-L = $2285-3642$ \\ Journal of Economic Development, Environment and People \\ Volume 9, Issue 2, 2020 \\ URL: http://jedep.spiruharet.ro \\ e-mail: office jedep@spiruharet.ro
}

population's structure according to the level of education in 2011 reveals a $20 \%$ population without school, more than a half with no more than primary school, and only $0.66 \%$ with tertiary education.

The European Commission 2018's Monitor, regarding Education and Training, reveals that Romania, during 2011- 2017, failed to fulfill the ET 2020's early leavers from education and training (ESL) target (below 10\%) registering $18.1 \%$. Although dropout rates in primary and lower secondary have decreased, the proportion of out-of-school children has increased, particularly in rural areas. [8, p.240]. The declining number of students requires the optimization of expenses at the same time as improving equity, by this work perspective, the ESL rate among Roma is alarmingly high at $77 \%[25$, p.36].

Despite the legislative revisions and the adoption of an anti-segregation roadmap [20], the Roma children are more predictable to drop out the school because of high levels of poverty, limited parental participation in education, a lower qualification of teachers in predominantly Roma schools and Roma traditions (such as: keeping women at home to preserve their 'cleanness' (i.e. virginity), be early married or/and to assume the carrying of other persons such as elders and small children).

Based on the 2011 Census of Population, the illiterate population was $14.1 \%$ from the total Roma population with better indicators for the active population (except for the unemployment looking for another job), but still ten times higher than the national average (1.4\%).

Regarding education, the NRIS 2015-2020 planned the implementation of a monitoring system in all schools where the share of Roma students is at least $15 \%$ in order to take action:

- to increase the number of pre-preschool and preschool Roma children who are not enrolled in kindergarten by according to their families the support to enroll children in kindergarten (they will benefit by the parental counseling, clothes, food, shortening of the time required to reach the nearest kindergarten, etc.) - 2020's target of 30,000 Roma children;

- to increase the participation rate in early (preschool) education of children 3-5 years old to $70 \%$ in 2020 (compared to $37 \%$ in 2011);

- to decrease the number of Roma children out of primary and secondary school by granting aid to enroll and effectively attend school courses in order to, until 2020, all Roma children aged 7-14 attend school;

- 40,000 Roma students benefit from support programs "School after school" during 2015-2020;

- 20,000 Romanian citizens belonging to the Roma minority will have improved their education level by participating to "Second chance" Program during 2015-2020;

- reduction from $14.1 \%$ in 2011 , to $10 \%$ in 2020 of illiterate persons. This implies the literacy of an additional 20,000 Romanian citizens belonging to the Roma minority by 2020 ;

- granting free transportation (based on the student card) to all vulnerable children (including Roma children) from rural areas;

- 50,000 parents of children from vulnerable categories (especially Roma) at risk of school dropout, beneficiaries of support to increase the chances of employment in the labour market (information, mediation and training) and 30,000 children from vulnerable categories (mainly Roma) at risk of school dropout will be the beneficiaries of programs meant to improve the socio-economic situation in the aspects that block their educational inclusion (food, clothes, living conditions, health status, etc.). 


\author{
(online) $=$ ISSN $2285-3642$ \\ ISSN-L = 2285-3642 \\ Journal of Economic Development, Environment and People \\ Volume 9, Issue 2, 2020 \\ URL: http://jedep.spiruharet.ro \\ e-mail: office jedep@spiruharet.ro
}

- the rehabilitation of all schools and the recruitment and employment of school mediators in all 1,680 educational establishments in which the number of Roma children and students is at least $15 \%$;

- 1,000 young Roma enrolled at the faculty in different places for Roma candidates until 2020 (compared to 600 in 2013);

- to increase the number of teachers initiated/ perfected in Romani language knowledge, principles of the inclusive school, knowledge, and application of the elements of history, culture of Roma;

- in all schools, school segregation is also prevented and eliminated.

According to Order no. 6134/ 21.12.2016, all school inspectorates have to monitor school segregation and report it to the Ministry of Education, as well as to propose remedial measures when identifying problems. In the absence of the methodological norms for monitoring segregation that is delayed, the authorities still refer to the 2007 Minister's Order. The methodology is still at the project stage, subject to public consultation in September 2019 and it is programmed to be applied in 3 counties (Constanta, Maramures, and lasi) of 42 at the national level for 2019-2020. The results for the pilot project are registered in a UNICEF electronic platform and are expected in April 2020.

The enrolment of Roma children in kindergarten remains at $38 \%$, and the trend is down. To stimulate participation in the preschool education of children in disadvantaged families and to increase their access to education, an educational incentive as social tickets, conditioned by the regular attendance to the kindergarten was granted. [7, p.8]

The number of support specialists (e.g. special education teachers, school counselors, Roma mediators, etc.) is insufficient. In 2016, 518 school mediators and Romani language teachers were registered (Horvath eds., 2017, p.299) of 1,156 school mediators trained [8, p.21].

According to Romanian Center for Legal Resources study in 2018, there were only 427 school mediators employed, despite the 1,900 school mediators trained since 2000 through a PHARE educational program [1] and the number is higher taking into account the graduates of training programs carried out under the National Authority for Qualifications. A school counselor is expected to work with 800 students, but, in practice, the student/counselor ratio is 2.5 times higher [9, p.4].

Although the NRIS intended to increase the number of Romani language teachers, this decreased from 640 in 2013, to 296 in the 2018-2019 school year. [1]

The Roma children and youth situation did not improve in the last 5 years despite the special 'reserved places' provided for them, because they are discouraged to enter of various motives and there are signals, in the lack of official statistics, that it is even worse in 'the field'.

'Young Roma people are discouraged to enter higher education by cultural factors, such as poor background, lack of family support, traditional role models, but also a difficult integration in the educational community.' [2]

It is a fact that education has the key role in employability and competitiveness in the labor market and correlated with the estimates according to which the population of Romanian citizens belonging to the Roma minority will continue to increase, both as number and share in the total Romanian population, the integration of Roma young population is a must, not only a wish. 


\author{
(online) $=$ ISSN $2285-3642$ \\ ISSN-L = 2285 - 3642 \\ Journal of Economic Development, Environment and People \\ Volume 9, Issue 2, 2020 \\ URL: http://jedep.spiruharet.ro \\ e-mail: office jedep@spiruharet.ro
}

In a study conducted by European Union Agency for Fundamental Rights (FRA), the Roma youth 'are associated with better social skills and greater flexibility in the face of a dynamically changing world, which helps increase social cohesion'. [10, pp.5-6]

\title{
4. Roma employment
}

Following the Europe 2020 objectives, the EU is focusing on economic growth and employment, but its measures are accompanied by deterioration in the quality of jobs all over Europe and long term mass unemployment in the South of Europe. [17, pp.80-81]

Since 1999, the International Labour Office (ILO) has promoted decent work for all, regardless of race, creed, sex, or country of origin. Decent work sums up the aspirations of people in their working lives as 'opportunities for women and men to obtain decent and productive work in conditions of freedom, equity, security, and human dignity'. [16, p.3]

Table 1. The Employment by ethnicity, people of 10 years and over

\begin{tabular}{|c|c|c|c|c|}
\hline \multirow{2}{*}{ ETHNICITY } & \multicolumn{2}{|c|}{2002} & \multicolumn{2}{|c|}{2011} \\
\hline & Total & $\%$ of the total & Total & $\%$ of the total \\
\hline ROMANIAN CITIZENS & $19,434,788$ & $100 \%$ & $18,022,221$ & $100 \%$ \\
\hline Active Population & $8,851,831$ & $45.5 \%$ & $9,180,337$ & $50.9 \%$ \\
\hline Employment & $7,811,733$ & $88.2 \%$ & $8,507,759$ & $92.7 \%$ \\
\hline Unemployment looking for another job & 655,557 & $7.4 \%$ & 434,308 & $4.7 \%$ \\
\hline Unemployment looking for the first job & 384,541 & $4.3 \%$ & 238,270 & $2.6 \%$ \\
\hline Inactive population & $10,582,957$ & $54.5 \%$ & $8,841,884$ & $49.1 \%$ \\
\hline Retired & $5,074,796$ & $48.0 \%$ & $4,268,347$ & $48.3 \%$ \\
\hline Others & $5,508,161$ & $52.0 \%$ & $4,573,537$ & $51.7 \%$ \\
\hline ROMA POPULATION & 408,842 & $100 \%$ & 477,715 & $100 \%$ \\
\hline Active Population & 122,573 & $30 \%$ & 158,136 & $33.1 \%$ \\
\hline Employment & 87,652 & $71.5 \%$ & 122,729 & $77.6 \%$ \\
\hline Unemployment looking for another job & 12,494 & $10.2 \%$ & 17,995 & $11.4 \%$ \\
\hline Unemployment looking for the first job & 22,427 & $18.3 \%$ & 17,412 & $11.0 \%$ \\
\hline Inactive population & 286,269 & $70 \%$ & 319,579 & $66.9 \%$ \\
\hline Retired & 30,613 & $10.7 \%$ & 34,976 & $10.9 \%$ \\
\hline Others & 255,656 & $89.3 \%$ & 284,603 & $89.1 \%$ \\
\hline
\end{tabular}

Source: Authors based on Romanian Census of population and housing 2002 and 2011

The labour market in our country still has an important informal component that contravenes the principles of decent work, higher employment at risk of poverty, an imbalance between labor market demand and educational supply and a social protection system that works inappropriately in many ways. [27] 


\author{
(online) $=$ ISSN $2285-3642$ \\ ISSN-L = 2285-3642 \\ Journal of Economic Development, Environment and People \\ Volume 9, Issue 2, 2020 \\ URL: http://jedep.spiruharet.ro \\ e-mail: office jedep@spiruharet.ro
}

The Roma population is about 63\% located in rural areas (2011 Census of Population) and, in Romania case, the people living in rural areas are generally more inclined to leave early education or training, in many cases because they are not supported to continue their studies and do not have the financial resources and the necessary school infrastructure. [28, p.60]

From 2002 to 2011, the Roma employment increases with 6 p.p based on decreasing both, inactive population and unemployment, too. (Table 1)

The inactive population has an important share of about $67 \%$ for the Roma minority in 2011 , decreasing compared with 2002, but much higher than the national average. In the number of the inactive population are included the population aged 10-15 years old even if in Romania persons under the age of 15 cannot be employed. If we corroborate with the fact that Roma population under 15 is about $34 \%$ (national average of $16 \%$ in 2011) the situation is slightly improved. (Table 1 )

Regarding unemployment, we observe that the situation of persons in searching for the first job improved, but one of those who tried to change their workplace it got worse. (Table 1)

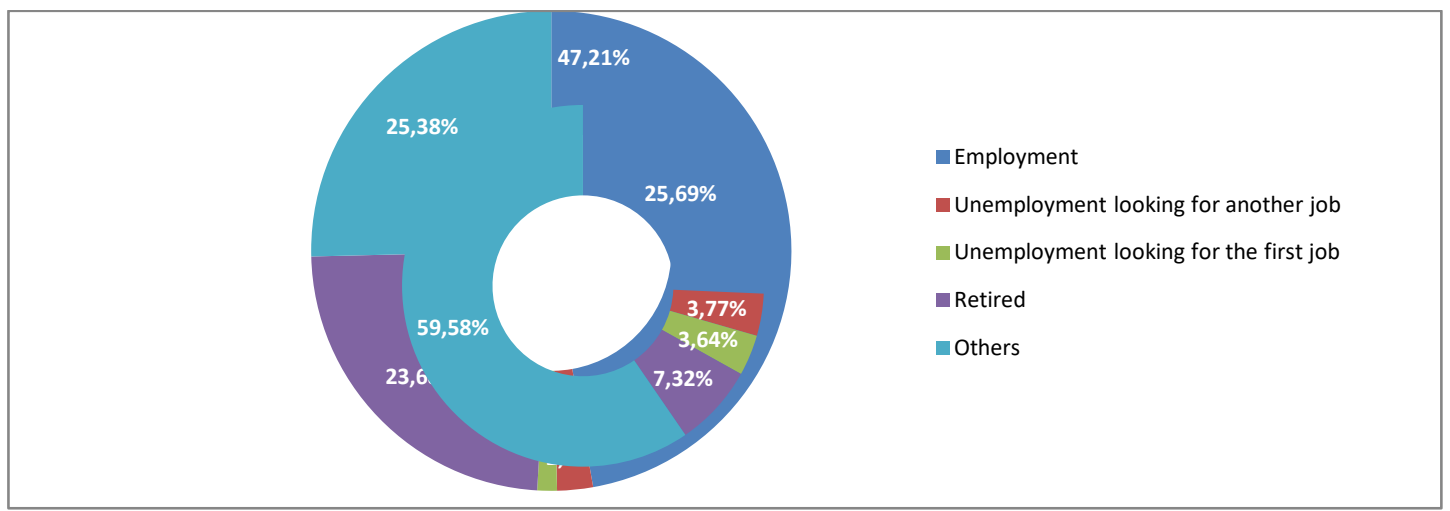

Fig. 1: Structure of employment of Romanian population, 10 years and over, belonging to Roma minority in 2011

Note: In white are the shares for Roma population and in black the one's for the total population in Romania

The NRIS 2015-2020 main objective of employment is to improve the participation in the labor market of Romanian citizens belonging to the Roma minority through actions such as:

- conducting information campaigns on the labor market to ensure the connection between employers and non-working Roma (free information, mediation, and counseling services for unemployed);

- facilitating the mobility of employment and entrepreneurship for citizens belonging to Roma minority (by granting employment bonuses, offering free consultancy to new employed);

- providing facilities for entrepreneurs that employ persons from disadvantaged groups.

Based on information on the Employment Agency, more than 50\% of the Roma employees leave the workplace in a very short time because of the small remuneration, the sustainability of the activity carried out (unskilled or seasonal work in construction) and problems related to discrimination at the workplace. [23, pp.16-17]

Another negative factor for Roma integration is limited and unequal access to employment. According to The European Commission against Racism and Intolerance (ECRI) 2019 Report (based on information 


\author{
(online) $=$ ISSN $2285-3642$ \\ ISSN-L = $2285-3642$ \\ Journal of Economic Development, Environment and People \\ Volume 9, Issue 2, 2020 \\ URL: http://jedep.spiruharet.ro \\ e-mail: office jedep@spiruharet.ro
}

collected until 6 December 2018) indicates that only 33\% of the employable Roma population (aged between 20-64) are in paid work (compared to $66 \%$ of the general population), while worryingly $64 \%$ of young persons (16-24 years old) are neither in employment nor in education (compared to $17 \%$ of the general population). Also, ECRI regrets to note that there is a strong employment gap between Roma women and men, which is not sufficiently addressed in the Strategy. [5, p.29]

Roma women have worse results compared to Roma men, both in the field of education and employment. Very low educational attainment may cause difficulties in achieving the criteria of the ILO's 'decent work' and only $21 \%$ of Roma women completed ISCED 3, 10\% of Roma women aged between 16-24 are in employment and $72 \%$ of them are neither in work nor in education or training (NEETs). [10] The Roma employment is likely to be: with a temporary contract', with an 'ad hoc contractual arrangement' or 'without a contract'.

\title{
5. Conclusion
}

The autonomies are very varied political configurations, deeply contextual of the consensual coexistence between majority and minority, which - in the case of design and functioning in professionalism's conditions - they prove to be effective tools for the protection of minorities in almost all regions of the world. They are successful if they achieve and maintain a balance between private and common interests of those concerned, and institutionalize an adequate proportion between separation and integration: they suppose an institutional system that separates different cultures only to a certain extent, advantageous for both parties, but it ensures their presence in the common public space, under the conditions of mutual tolerance and respect. [32, pp.48-49]

The inclusion of the Roma brings with it the creation of an intelligent economy in Romania. With an aging population and a young and developing Roma minority, Romania cannot afford to leave behind Roma children and young people and their families. [36]

The lack of data/information is a concern of both, international and national authorities; in this direction, ECRI regrets that there is still no comprehensive system for the collection of data to assess the scale of discrimination of groups of concern to ECRI, including Roma [5, p.24] and the National Agency for Roma complains on:

- the lack of a system of monitoring and evaluation of the NRIS's measures;

- the lack of a methodology of technical coordination of the experts within the County Offices for Roma (BJR);

- the lack of sociological research instruments to identify the problems faced by the Roma communities at the local level;

- the lack of effective communication with the decision-makers, both at the county and national level, in the process of planning measures in the field of Roma inclusion;

- the lack of protocols and intervention methodologies in cases of Roma evictions and cases of discrimination or conflicts based on racial hatred;

- lack of permanent monitoring mechanisms of the projects/programs implemented for the benefit of the Roma with non-reimbursable financial resources; 


\author{
(online) = ISSN $2285-3642$ \\ ISSN-L = $2285-3642$ \\ Journal of Economic Development, Environment and People \\ Volume 9, Issue 2, 2020 \\ URL: http://jedep.spiruharet.ro \\ e-mail: office jedep@spiruharet.ro
}

- the lack of a data collection mechanism that will help NAR in the process of analyzing the size of the Roma problem to make public policy recommendations. [22, p.2], [23]

Living in marginalized conditions and poverty affects young Roma's employment opportunities in multiple ways. At the educational stage, poverty weakens human capital formation and prevents young people from gaining the knowledge they need to successfully compete in the labor market. But poverty also affects the very process of transition and its outcome leading to a waste of human capital. Therefore, poverty should be addressed as a multidimensional phenomenon matching active labor market policies (to facilitate access to better quality jobs) and social policy instruments (to address the negative implications of poverty for human capital formation while the impact of better quality jobs and higher incomes comes into effect). [10 p.35]

\title{
6. Acknowledgments
}

The paper was presented on the First ENTAN conference Non-Territorial Autonomy as a Form of Plurinational Democracy: Participation, Recognition, Reconciliation in Belgrade, Serbia, 22 \& 23 November 2019.

\section{References}

[1] A.M. Ciobanu (2019). Cum monitorizăm segregarea școlară? (How do we monitor the school segregation?), Scoala 9. published on 23 Octombrie, URL: https://www.scoala9.ro/cum-monitorizam-segregarea-scolara-/487/ (accessed on 5 November, 2019)

[2] D.M. Cismaru, C. Fiţ and D. Gologan (2015). Premises of Inclusive Access and Success of Roma People in the Romanian Higher Education. In: Curaj A., Matei L., Pricopie R., Salmi J., Scott P. (eds.) The European Higher Education Area. Springer, Cham, https://doi.org/10.1007/978-3-319-20877-0_33

[3] I. A. Crăciun (2009).Tiganii din România: captivi într-o lume paralelă (Gypsies from Romania: captives in a parallel world), Evenimentul zilei, 12 septembrie (accessed on 2 October, 2019)

[4] J. Coakley (2016). Introduction: Dispersed Minorities and Non-Territorial Autonomy, Ethnopolitics 15 (1):1-23

[5] ECRI (2019). ECRI Report on Romania (fifth monitoring cycle), URL: https://rm.coe.int/ fifth-report-onromania/168094c9e5 (accessed on 2 October, 2019)

[6] European Commission (2011). An EU Framework for National Roma Integration Strategies up to 2020, Brussels, URL: https://ec.europa.eu/health/sites/health/files/social_determinants/docs/com2011_173_en.pdf (accessed on 8 September, 2019)

[7] European Commission DG-JC (2018). Civil society monitoring report on implementation of the national Roma integration strategy in Romania. Focusing on structural and horizontal preconditions for successful implementation of the strategy, URL: https://op.europa.eu/en/publication-detail/-/publication/3106a14d-b1ac11e9-9d01-01aa75ed71a1/language-en/format-PDF/source-105838959 (accessed on 10 October, 2019)

[8] European Commission DG-EAC (2018). Education and Training Monitor 2018, Brussels, URL: https://ec.europa.eu/ transparency/regdoc/rep/10102/2018/EN/SWD-2018-435-F1-EN-MAIN-PART-3.PDF (accessed on 10 October, 2019) 


\author{
(online) = ISSN $2285-3642$ \\ ISSN-L = $2285-3642$ \\ Journal of Economic Development, Environment and People \\ Volume 9, Issue 2, 2020 \\ URL: http://jedep.spiruharet.ro \\ e-mail: office jedep@spiruharet.ro
}

[9] European Commission (2019). Education and Training Monitor 2019. Romania, URL: https://cdn.edupedu.ro/wpcontent/uploads/2019/09/Monitorul-european-pe-educatie-2019-Romania.pdf (accessed on 2 November, 2019)

[10] European Union Agency for Fundamental Rights - FRA (2018). Second European Union Minorities and Discrimination Survey. Roma - Selected findings, URL: https://fra.europa.eu/sites/default/files/fra_uploads/fra2016-eu-minorities-survey-roma-selected-findings_en.pdf (accessed on 8 September, 2019)

[11] EU Roma (2018). Assessment of the mid-term review of the EU Framework for National Roma Integration Strategies up to 2020, URL: https://www.euromanet.eu/wp-content/uploads/2019/01/EUROMA_Positionpaper_Midterm-Assessment-EU-Framework-NRIS-2020_final.pdf (accessed on 8 September, 2019)

[12] European Union Agency for Fundamental Rights (FRA) (2018). Transition from education to employment of young Roma in nine EU Member States, Luxembourg: Publications Office of the European Union, URL: https://fra.europa.eu/en/publication/2018/roma-education-to-employment (accessed on 8 November, 2019)

[13] J.H. Friberg (2018). Poverty, networks, resistance: The economic sociology of Roma migration for begging, Migration Studies, pp.1-22, URL: https://academic.oup.com/ migration/advancerticle/doi/10.1093/migration/mny038/5163084\#123982456

[14] F. Ghencea and I. Nicolau (2008), Aspects regarding positive discrimination,, Eurodreptul 2, Craiova: 109-115

[15] Human Development and Sustainable Development Teams - Europe and Central Asia (2014), Achieving Roma Inclusion in Romania - What Does It Take?, URL: http://documents.worldbank.org/curated/en/52239146814 4557916 /Raport-de-sinteza (accessed on 12 September, 2019)

[16] ILO (1999), Report of the Director-General: Decent Work, 87 Session, Geneva, June, available at: http://www.ilo.org/public/english/standards/relm/ilc/ilc87/rep-i.htm (accessed 10 September, 2019)

[17] B.A. Lundvall and E. Lorenz (2014). The Euro Crisis and the Failure of the Lisbon Strategy, Structural Change, Competitiveness and Industrial Policy: Painful Lessons from the European Periphery, UK: Routledge Taylor and Francis.

[18] A. Marin and A. Csonta (2013). Discrimination of Roma Communities. Romania National Report, URL: http://www.crj.ro/userfiles/editor/files/National\%20Report\%20Romania_NET-KARD.pdf

[19] Ministry of National Education and Scientific Research (2016). Framework-Order of the Minister of National Education and Scientific Research no. 6134 / 21.12.2016 on the prohibition of school segregation in preuniversity education units, available at www.edu.ro

[20] Ministry of National Education and Scientific Research (2016). Order of the Minister of National Education and Scientific Research no. 6158 / 22.12.2016 for the adoption of the Action Plan for school desegregation and the increase of the educational quality in the pre-university education units in Romania, available at www.edu.ro

[21] NAR (2010). High Level Event - Contribution of EU funds to the integration of Roma, Bucharest, 12-13 October, URL: http://www.anr.gov.ro/docs/proiecte_actualizate/prezentare\%20ro_en.pdf (accessed on 8 September, 2019)

[22] NAR (2017). Report of Activity 2017, URL: http://www.anr.gov.ro/docs/Site2017/Rapoarte /raport\%20anual\%20de\%20activitate\%20ANR_2017.pdf

[23] NAR (2018). Report 2017. Monitoring the implementation stage of the measures found in the strategy of the Romanian Government for the inclusion of Romanian citizens belonging to the Roma minority for the period 


\author{
(online) $=$ ISSN $2285-3642$ \\ ISSN-L = $2285-3642$ \\ Journal of Economic Development, Environment and People \\ Volume 9, Issue 2, 2020 \\ URL: http://jedep.spiruharet.ro \\ e-mail: office jedep@spiruharet.ro
}

2015-2020, respectively GD 18/2015, URL: http://www.anr.gov.ro/docs/Site2018/Rapoarte/HG182015/1.\%20Raport\%20anual\%2020 17\%20monitorizare\%20HG18_2015.pdf

[24] National Institute of Statistics (NIS). Census of population and housing 2002 and 2011, URL: http://www.recensamantromania.ro/rezultate-2/

[25] V. Naydenova and M. Matarazzo (2019). Post-2020 EU Roma Strategy: The way forward, URL: https://www.opensocietyfoundations.org/uploads/7004b0da-956d-4df9-a1f7-d889a00ae9d5/post-2020-euroma-strategy-the-way-forward-20190627.pdf (accessed on 8 September, 2019)

[26] A. Pană (2015). Implementation of the National Roma Integration Strategy and Other National Commitments in the Field of Health. Romania. A multi-stakeholder perspective report on 2005-2014 developments, URL: https://oim.ro/attachments/article/0/Romania_Progress\%20Report.pdf (accessed on 8 September, 2019)

[27] L. Patache and M. Bebeșelea (2017). Aspects regarding the Quest for Decent Job for Romanian Worker, Constanta: International Conference on Law and Social Order LSO 2017, 20-21 October 2017

[28] L. Patache, C. Chiru and M. Bebeselea (2018). Rural Employment and Decent Work in Romania, Annals of Spiru Haret University. Economic Series 18(2):53-62, DOI: https://doi.org/10.26458/1822

[29] Romanian Constituent Assembly, Constitution of Romania, published in Official Gazette Part I, no. 767/2003

[30] Roma Education Fund (2007).Evolutia Educatiei Romilor in Romania. Evaluare a tarii si directiile de actiune strategice ale Fondului de Educatie pentru Romi (The evolution of Roma education in Romania. Country assessment Romania, Roma Education Fund), URL: https://www.romaeducationfund.org/wpcontent/uploads/2019/05/web_romania_report_romanian.pdf (accessed on 6 October, 2019)

[31] Romanian Government (2015). Strategy for the Inclusion of the Romanian Citizens belonging to Roma Minority for 2015-2020, published in Official Gazette no.9/2015 URL:

http://www.anr.gov.ro/docs/Site2015/ANR/Strategia/Anexa\%20Strategie.pdf (accessed on 15 September, 2019)

[32] L. Salat (2006).Forme de autonomie şi condiţiile de realizabilitate ale acestora (Forms of autonomy and conditions of their feasibility), Altera, XII (29):37-49, URL: http://altera.adatbank.transindex.ro/pdf/29/003.pdf (accessed on 4 November, 2019)

[33] D. Sandu (2005). Comunităţile de Romi din România. O hartă a sărăciei comunitare prin sondajul PROROMI (Romanian communities of Roma. A minority poverty map through PROROMI research), URL: http://www.anr.gov.ro/docs/statistici/PROROMI_Comunitatile_de_Romi_din_Romania_187.pdf (accessed on 8 September, 2019)

[34] L. Surdu and M. Wamsiedel (coord.) (2011). Country assessment Romania, Roma Education Fund, URL: http://romaeducationfund.ro/wp-content/uploads/2015/01/ENG_Country-Assesment-Romania-20121.pdf (accessed on 2 September, 2019)

[35] UNICEF (2011). The Right of Roma Children to Education. Position Paper, Geneva, URL:https://www.unicef.org/ eca/media/1566/file/Roma\%20education\%20postition\%20paper.pdf (accessed on 6 October, 2019)

[36] World Bank (2014). Ce este necesar pentru realizarea incluziunii romilor din România? (What is required for the inclusion of Roma in Romania?). URL:https://www.worldbank.org/content/dam/Worldbank/document/eca /romania/Summary\%20Report\%20RomanianAchievingRoma\%20Inclusion\%20RO.pdf 